\title{
Development Of Payment System: Case Of Central Bank Of Bahrain
}

Moade Fawzi Shubita, New York Institute of Technology, USA

Peter Harris, New York Institute of Technology, USA

Abdulla Ahmed Felaifel, New York Institute of Technology, USA

\begin{abstract}
This study analyses the payment system of the Central Bank of Bahrain based on interviews with bankers in addition to distributing 70 questionnaires to seven banks. The study presents the historical development of the Central Bank of Bahrain and reviews related studies. The results show that the value relevance of the payment system is important and there are various new tools for implementing this system. Further, the analysis reveals that there is a need to develop the infrastructure to fit the needs of Bahrain as the financial capital of the Middle East.
\end{abstract}

Keywords: Central Bank of Bahrain; e-Banking; Bahrain; Payment System

\section{INTRODUCTION}

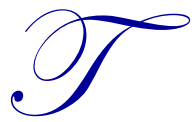

he payment system is an essential part of the financial infrastructure in every country. In this age of growing financial integration and inter-dependence within and across countries, it has become all the more important for every payment system to be more efficient, reliable and safe. This is to ensure sound monetary management through market-oriented monetary instruments and efficient payment services to the financial system and the real sector in the country. Furthermore, a payment system influences the speed, financial risk, reliability and cost of domestic and international transactions. Therefore, continuous development of the financial infrastructure, including reforms to the payment system, has been a top priority among all the Central Banks in the world. This study attempts to analyse the evolution of the payment system in the Kingdom of Bahrain, with particular emphasis on the increased use of technology in operations and the resultant benefits to the users. The sustained and continuous growth in the payment system infrastructure is fundamentally important, as the Kingdom of Bahrain is considered the financial capital of the Middle East (Dew, 2003). The Central Bank of Bahrain is a key driver for enabling this position and, in this respect, this study assumes great significance.

Several types of payment systems have evolved over the past two decades in Bahrain, including currency, cheques, ATMs, e-banking and the Real Time Gross Settlement System (RTGS). The study utilises a questionnaire distributed to the key commercial banks in the country in order to analyse the impact of introducing the RTGS and cheque imaging system to Bahrain. Further, an interview with key banking personnel has been conducted to assess the most influential factors behind the growth of the payment system in Bahrain.

The remainder of this paper is organised as follows: Section 2 provides a brief summary of the historical development in the Bahraini Monetary System, Section 3 literature review, Section 4 methodology of the study, and Section 5 presents results and conclusions.

\section{HISTORICAL DEVELOPMENTS IN THE BAHRAINI MONETARY SYSTEM}

The economy in Bahrain is based on oil, the banking industry and tourism. The focus of this study is the banking industry, specifically the real time payment settlement. To achieve this objective, a brief introduction to the development of the banking industry in Bahrain is worth reviewing. The Bahrain Currency Board was established in 1964. This board led to the introduction of the Bahraini Dinner in 1965. Then, the Bahrain Monetary Agency (BMA) was established in 1973 as the central bank and the bank regulator for Bahrain. The BMA has maintained a 
fixed exchange rate against the United States dollar since 1980. This has provided Bahrain with a high degree of economic and price stability, while encouraging the growth of the economy. In 2006, the Central Bank of Bahrain (CBB) and Financial Institutions was established as the successor to the BMA.

\section{LITERATURE REVIEW}

As one of the main roles of the CBB is to maintain an effective payment system, it is worth discussing recent papers focusing on different central banks worldwide. Ben and Falko's (2011) study addresses factors that drive the relative importance of net and gross settlement systems over the short run, using daily data on transaction volumes from the large-volume payment systems of all Eurozone countries that have had simultaneous net and gross settlement systems. Based on a large portfolio of different econometric techniques, they find that it is actually the transaction volumes in gross settlement systems that affect the daily price of liquidity and the credit risk spread in money markets. While Ronald et al. (2010) investigate the Euro unsecured interbank money market during the current financial crisis and it led to developing a policy tool to monitor the interbank money market, both at macro level and individual bank level. Fullwiler (2009) utilises the social fabric matrix approach (SFM-A) to provide a detailed description of the Federal Reserve's (Fed's) daily operations. Overall, the Fed's operations are driven by the goals of the payment and financial systems. Other major norms were addressed in the study along with three additional general principles of the Fed's operations. Ben et al. (2011) argue that modern central banks have come to view payment systems as a key area of strategic interest, both as part of their responsibilities for financial stability and for the implementation of monetary policy. As a final example of recent studies in this field, Marcelo et al. (2011) examine the robustness of the payment system based on two different hypothetical behaviour changes: either banks stop sending payments due to operational problems or it pays exactly what it previously received. This study derives probabilistic statements about the time at which the bank's counterparties expect to run out of liquidity.

\section{METHODOLOGY OF THE STUDY}

The study collects primary data based on a designed questionnaire submitted to seven banks in the Kingdom of Bahrain: CBB; National Bank of Bahrain; Bank of Bahrain \& Kuwait; HSBC Bank Middle East Limited; Kuwait Finance House; Khaleej Commercial Bank; and Bahrain Muscat Bank. Each bank employs 10 staff. This combination includes the CBB and various types of banks operating in Bahrain, of which it includes public shareholder national, regional banks and private global banks, thereby reflecting the variety in the Bahrain market. Ten questionnaires were distributed and collected for each bank. This makes a total of 70 questionnaires considered as a sample of the study.

\section{RESULTS AND CONCLUSION}

SPSS was used to analyse the data and various statistical tools were employed to analyse the results and draw conclusions. The results show that the distribution of correspondents based on gender was 39 male and 31 female; $54.7 \%$ and $44.3 \%$ respectively. In terms of education, $12 \%$ of respondents hold a degree lower than bachelor, $74 \%$ have a BS degree, while $24 \%$ hold an MBA degree. This shows that correspondents have sufficient qualifications to answer the questions with high credibility. In relation to age, $62 \%$ of correspondents' were aged between 26 and 35 years, while $22 \%$ were younger than 26 years and $16 \%$ older than 35 years. The questionnaire includes 10 statements on 5-Likert scale. The following table shows the average score for each statement with the standard deviation.

The results show that positive answers regarding the value relevance of payment system in terms of its positive impact on various dimensions of the banking system as indicated in statements 5, and 7 to 10 . Further, positive results in statements 4 and 6 comply with the fact that there are various forms related to payment systems. In relation to the results for the Kingdom of Bahrain, the first two statements show that the payment system is important, especially as the Bahrain government works towards securing the country as the financial capital of the region. However, the infrastructure related to this small kingdom is still not customised for the Bahraini system, as the results for statement 3 indicate a score less than 4. Based on interviews with bank officers, it was revealed that the introduction of new systems, particularly the RTGS and cheque imaging, has been proposed to respond to the claim that the current system may not be as effective. RTGS as a new system used mainly to ease the burden of the 
settlement process would greatly enhance the payment system in order to resolve issues involving risks and timelags. It is valuable in reducing risk factors, such as liquidity risks, where flexibility is greatly threatened and credit risk, where value in terms of settlement is critical.

\begin{tabular}{|c|c|c|}
\hline Statement & Mean & $\begin{array}{c}\text { Std. } \\
\text { Deviation }\end{array}$ \\
\hline 1. Does the payment system in Bahrain use new technology at the moment? & 4.11 & .925 \\
\hline $\begin{array}{l}\text { 2. The payment system infrastructure is fundamentally important as the Kingdom of Bahrain is } \\
\text { considered the financial capital of the Middle East. }\end{array}$ & 4.17 & .963 \\
\hline $\begin{array}{l}\text { 3. Types of payment systems and technologies are available today with specific reference to } \\
\text { Bahrain. }\end{array}$ & 3.80 & .910 \\
\hline $\begin{array}{l}\text { 4. Payment systems have many different technologies, such as RTGS, cheques, ATMs, e- } \\
\text { banking, etc... }\end{array}$ & 4.16 & .845 \\
\hline 5. Payment system has been a top priority among all the Central Banks worldwide. & 4.01 & .771 \\
\hline $\begin{array}{l}\text { 6. Payment instruments take many forms, such as cash, cheques, traveller's cheques, money } \\
\text { orders, debit and credit cards, wire transfers, automated clearinghouse transfers, and point- } \\
\text { of-sale and automated teller machines. }\end{array}$ & 4.31 & .790 \\
\hline $\begin{array}{l}\text { 7. The payment system is very important to the economy, as it routes all the payment transfers } \\
\text { in the country. }\end{array}$ & 4.06 & .915 \\
\hline 8. The payment system is an essential part of the financial infrastructure of every country. & 4.30 & .749 \\
\hline $\begin{array}{l}\text { 9. The payment system influences the speed, financial risk, reliability and cost of domestic and } \\
\text { international transactions. }\end{array}$ & 4.19 & .921 \\
\hline $\begin{array}{l}\text { 10. The payment system is the lifeline of an economy. It facilitates payment and settlement } \\
\text { among the economic agents. It facilitates fund transfers within and across countries. }\end{array}$ & 4.14 & .856 \\
\hline
\end{tabular}

RTGS is also presented as a solution that would increase the speed and time-lags present in the current system. As analysed in the questionnaire results, it is easy to introduce due to the familiarity of the concerned population with it and the willingness to accept its implementation. RTGS as a centralised tool in the settlement process would be crucial in its influence over the payment system if it was to be introduced.

As for cheque imaging, the amount of time spent on the current system (i.e. cheque clearing) and the obsoleteness of the current system allowed its introduction as an alternative to cheque clearing. The new technology that comes with cheque imaging would greatly increase the speed and efficiency of the cheque flow. This is one of the changes that would also demonstrate how technology can greatly improve the payment system in its evolution. The question of familiarity also needs to be considered, despite the fact that many have asserted their knowledge of it.

Both the new systems of RTGS and cheque imaging will be introduced to the Kingdom of Bahrain. When this implementation occurs, a further assessment of these systems is expected and recommended. In addition, the introduction of RTGS and cheque imaging might also lead to other needs that may not be foreseen unless the systems are implemented. Other technological advances have led to further developments in the payment system (such as e-banking), which no doubt will lead to the introduction of more aspects that will enhance the payment system.

This study analysed the current infrastructure of payment systems in the CBB based on the assessment of bankers in the field and on various interviews. Further, this study should be replicated in different sectors or geographical areas to help achieve the generalizability of findings, starting from the gulf region then extending to other regions.

\section{AUTHOR INFORMATION}

Moade Fawzi Shubita is a Full Professor of Accounting and holds a PhD Degree in Accounting from the University of Manchester, UK (AACSB accredited) in 1999. He maintained a solid publication record in Accounting and Finance mainly in the line of Market Based Accounting Research. He has authored, co-authored, edited and peer-reviewed many publications. In addition to lecturing in many conferences, supervising Masters' Doctorate 
theses and run several projects with the industry in order to enhance the quality of education. He is Certified Management Accountant (CMA) and member with IMA. E-mail: moade shubita@ hotmail.com or moade.f.shubita@gmail.com (Corresponding author)

Professor Peter Harris, Ph.D., is a Professor and Chair of the Accounting and Finance department at the New York Institute of Technology. Previously he had worked for Ernst and Young LLP. He is an author of over 30 refereed journal articles and has presented and continues to present seminars to nationally and globally audiences on topics relating to financial reporting and taxation. $\mathrm{He}$ is a member of several professional organizations. E-mail: pharris@nyit.edu

Abdulla Ahmed Felaifel, is the Operation Executive at National Bank of Bahrain with responsibility for Cards Center Operation. He also served as the Cards Operation Executive in the Payment system and how to develop the system. Abdulla holds a Master of Business Administration degree with honour from the New York Institute of

Technology and Bachelor degree in Accounting from the same Institution. The current research is based on Abdulla's MBA thesis supervised by Dr. Moade Shubita. E-mail: abdulla.felaifel@windowslive.com

\section{REFERENCES}

1. Dew, P. (2003), Kingdom of Bahrain the financial capital of the Middle East. London: Euromoney Books, Nestor House, Playhouse Yard in association with The Bahrain Monetary Agency.

2. Ben, R. C., \& Falko, F. (2011), Substitution between net and gross settlement systems: A concern for financial stability? FRB of Cleveland Policy Discussion. pp. 11-32.

3. Ronald, H., Heuver, R., \& Walraven, D. (2010), Monitoring the Unsecured interbank money market using target2 data. De Nederlandsche Bank Working. p. 276.

4. Fullwiler, S. T. (2009), The social fabric matrix approach to central bank operations- an application to the federal reserve and the recent financial crisis.

5. Ben, N., Shaw, R., \& Speight, G. (2011), The history of interbank settlement arrangements: Exploring central banks' role in the payment system. Bank of England, working paper. p. 412.

6. Marcelo, P., \& Schanz, J. F. (2011), System-wide liquidity risk in the United kingdom's large-value payment system: An empirical analysis. (Working paper). Bank of England. p. 427. 